\title{
SOEP
}

SOEPpapers

on Multidisciplinary Panel Data Research

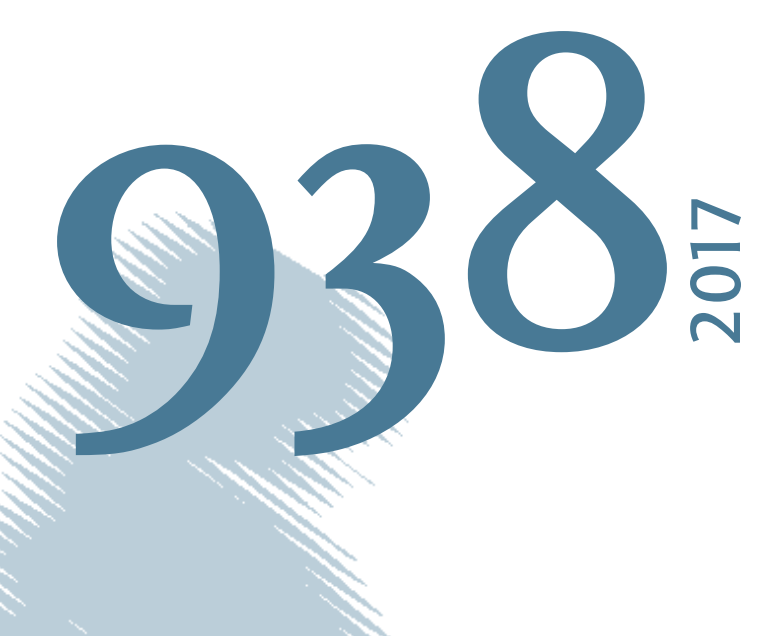

\section{The Space of Capital: A Latent Class Analysis of Capital Portfolios in Germany}


This series presents research findings based either directly on data from the German SocioEconomic Panel study (SOEP) or using SOEP data as part of an internationally comparable data set (e.g. CNEF, ECHP, LIS, LWS, CHER/PACO). SOEP is a truly multidisciplinary household panel study covering a wide range of social and behavioral sciences: economics, sociology, psychology, survey methodology, econometrics and applied statistics, educational science, political science, public health, behavioral genetics, demography, geography, and sport science.

The decision to publish a submission in SOEPpapers is made by a board of editors chosen by the DIW Berlin to represent the wide range of disciplines covered by SOEP. There is no external referee process and papers are either accepted or rejected without revision. Papers appear in this series as works in progress and may also appear elsewhere. They often represent preliminary studies and are circulated to encourage discussion. Citation of such a paper should account for its provisional character. A revised version may be requested from the author directly.

Any opinions expressed in this series are those of the author(s) and not those of DIW Berlin. Research disseminated by DIW Berlin may include views on public policy issues, but the institute itself takes no institutional policy positions.

The SOEPpapers are available at http://www.diw.de/soeppapers

\section{Editors:}

Jan Goebel (Spatial Economics)

Martin Kroh (Political Science, Survey Methodology)

Carsten Schröder (Public Economics)

Jürgen Schupp (Sociology)

Conchita D'Ambrosio (Public Economics, DIW Research Fellow)

Denis Gerstorf (Psychology, DIW Research Director)

Elke Holst (Gender Studies, DIW Research Director)

Frauke Kreuter (Survey Methodology, DIW Research Fellow)

Frieder R. Lang (Psychology, DIW Research Fellow)

Jörg-Peter Schräpler (Survey Methodology, DIW Research Fellow)

Thomas Siedler (Empirical Economics, DIW Research Fellow)

C. Katharina Spieß (Education and Family Economics)

Gert G. Wagner (Social Sciences)

ISSN: 1864-6689 (online)

German Socio-Economic Panel (SOEP)

DIW Berlin

Mohrenstrasse 58

10117 Berlin, Germany

Contact: soeppapers@diw.de

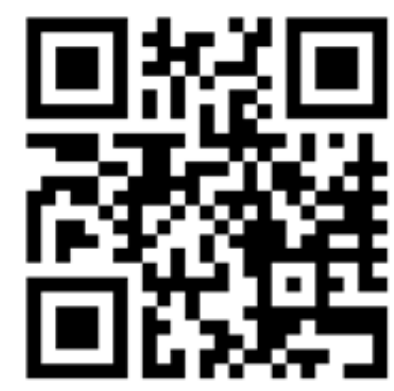




\title{
The Space of Capital: \\ A Latent Class Analysis of Capital Portfolios in Germany
}

\author{
Nora Waitkus \& Olaf Groh-Samberg \\ University of Bremen
}

\begin{abstract}
:
The aim of this paper is to construct the "space of capital" based on disaggregated measures of capital portfolios and to analyze the dynamics of class mobility over time. Drawing on Pierre Bourdieu's concept of the "social space", we argue that it is possible to directly assess the structural dimensions of the social space as a space of (economic and cultural) capital, including wealth as an important but often neglected form of economic capital. Using household panel data from 2002-2012 (SOEP), we apply latent class analysis in order to detect distinct classes based on specific capital portfolios. We find nine classes with diverging capital portfolios. When interpreting the nine latent classes, we find clear evidence for the two main axis of the social space, namely the vertical axis of the overall volume of capital, and the horizontal axis representing the composition of capital in terms of the relative weight of economic and cultural capital. Further exploration of class mobility reveals that the horizontal axis is even more stable over time. Most mobility occurs along the vertical axis of the social space, while there is only little horizontal mobility indicating that individuals rarely change their investment and accumulation strategies. This research adds to Bourdieu inspired class analysis as well as sociological perspectives on wealth and accumulation.
\end{abstract}

Keywords: social space, Bourdieu, capital, social class, wealth, mobility, latent class analysis 


\section{Introduction}

Bourdieu's concept of the social space is a powerful tool for analyzing social inequality in contemporary societies (Bourdieu 1984). His theory combines a structural dimension of various types of resources - called capitals - with a theory of social and cultural practices. As a relational approach it refers to the relative differences of resources (here: capitals) and elements of cultural practices between individuals or social groups, rather than the absolute level of resources or on substantial forms of cultural practices. Bourdieu's central argument is that the structural dimension of the social space is homologous to the system of differences and oppositions that underlie and structure the social and cultural practices, i.e., the space of lifestyles. This homology is caused by socialization effects which are inherent to the processes of attaining and reproducing various forms of capitals by individuals or families. This theoretical framework allows for a dynamic understanding of social classes: Social classes can be understood as groups of individuals which share similar experiences of acquiring and reproducing certain sets of capitals, via both family socialization and status attainment processes over the life course.

Research following Bourdieu has mainly focused on the concept of cultural capital (see Lareau and Weininger 2003; Prieur and Savage 2013) and the space of cultural practices or lifestyles (Bennett et al. 2009; Le Roux et al. 2008). With regard to Bourdieu's theory of capitals, cultural capital has been much more extensively discussed and employed than economic capital. Accordingly, little attention has been paid to the entire distribution of economic and cultural capital and, thus, the structural dimension of the social space. Following Bourdieu's original methodological approach, Multiple Correspondence Analysis (MCA) has been applied to indicators of cultural practices and preferences in order to explore the structuring of the space of lifestyles (for an overview see Coulangeon and Duval 2014). The resulting structure of the space of lifestyles is assumed to simply mirror the structure of the space of capitals. Empirically, this assumption is often tested, or merely illustrated, by plotting indicators of education, occupations or income onto the space of lifestyles (e.g. Bourdieu 1984, 262).

Our analysis in this paper deviates from these approaches in several respects. First, we aim at directly assessing the structural dimension of the social space, as a space of capitals. We argue that the concept of the social space provides a multidimensional approach to social stratification research, combining economic and cultural capital, which has been largely neglected so far (but see e.g. Savage 2015; Savage et al. 2013). Second, a main advantage of Bourdieu's concept of the 
social space is that it easily allows integrating various dimensions of economic capital, including wealth. This is particularly important since classical approaches to social class have acknowledged wealth only as business assets, but not as a decisive dimension of social stratification (Savage 2014; Savage 2015). Occupation-based approaches to social class (for example Erikson and Goldthorpe 1992; Weeden and Grusky 2005; Wright 1997) exert particular difficulties in acknowledging wealth as a crucial dimension of social class, simply because wealth is more independent from occupations than (labor) income (Savage 2015). Thirdly, our analysis focuses on the horizontal dimension of the social space as defined by the relative composition of economic and cultural capital. For Bourdieu, the differences in the relative composition of capitals are the main determinant for socio-cultural and socio-political conflicts within the "ruling classes", between its (dominated) cultural and (dominating) economic pole. While these horizontal disparities or class cleavages have been neglected in uni-dimensional or gradational approaches to social stratification (or have been misunderstood as status inconsistencies), we follow Bourdieu's argument that cultural and economic capital represent two distinct and even conflicting forms of legitimate power in contemporary capitalist societies (Bourdieu 1987). While we cannot test this assumption to its full extent, we nevertheless, fourthly, take into account the dynamic perspective on the social space by assessing intragenerational class mobility over time. Finally, we use Latent Class Analysis (LCA), rather than MCA, for our empirical analysis. LCA is a clustering approach based on categorical variables in our case, various dimensions of economic and cultural capital - that allows for identifying social classes based on their specific capital portfolios (see Savage et al. 2013 for a similar approach).

This chapter is structured as follows: First, we discuss Bourdieu's concept of the social space and highlight the main features for the purpose of our analysis. Section two describes data and methods. In section three we present our results. We first describe the nine social classes obtained from LCA of cross-sectional capital portfolios. Subsequently, we exploit the longitudinal nature of the data and present mobility patterns over time. Section four concludes. 


\section{Theoretical Outline: The Space of Capital}

We propose an empirical approach to social classes based on a direct assessment of the structural dimension of the social space, as a space of capital. In the following we first briefly discuss Bourdieu's theoretical understanding of the social space before we offer a conceptualization for an empirical assessment of the space of capital.

The structure of the social space

In "Distinction" (1984), Bourdieu established the concept of the social space as a distinct approach to social class analysis. Bourdieu himself, and most of the research following him, employed correspondence analysis to various measures of cultural practices and tastes. He argues that the resulting "space of lifestyles" is homologous to the space of social positions. This argument was empirically supported by plotting some direct indicators of economic resources (namely income) and formal educational qualifications onto the space of lifestyles (Bourdieu 1984: 262).

Bourdieu argues that the two main axis of the space can be interpreted as a vertical axis representing the overall volume of capital, and a horizontal axis representing the relative composition of the two most dominant types of capital, namely economic and cultural capital. A third axis of the social space is characterized as the social trajectory, capturing the intergenerational as well as life-course mobility of individuals (Bourdieu 1987, 4). An important feature of Bourdieu's social space is that the horizontal differentiation between the cultural and the economic pole becomes stronger as one move upwardly along the vertical axis. It is thus within the upper classes where the division into an economic and a cultural fraction is most pronounced, represented by the ascetic and highly cultured practices of arts and intellectuals on the one hand, and the conspicuous luxury consumption of the rich, on the other (Bourdieu 1989). Whereas the middle classes are stratified along this horizontal axis as well - reflecting their strong orientations towards the bourgeoisie classes - the horizontal divide is almost absent in the working classes.

The horizontal differentiation into a dominantly cultural and a dominantly economic pole of the ruling classes refers not only to symbolic distinctions, but also to the underlying struggles about 
the legitimate principles of domination. For the "dominated fractions of the dominating classes" (Bourdieu 1984, p.470), this is money, but in its legitimized forms of successful economic entrepreneurship, industrialism, and venture capital, representing the productive forces that bring all the progress and fortune to modern societies. For the "dominated fractions of the dominating classes" (ibid.), the most legitimate principle of domination is knowledge, expertise, culture, in its most exceptional forms of universal reason and its strongest institutional manifestation in the modern state, or the "state nobility" (Bourdieu 1996). While Bourdieu is very clear about the dominance of economic capital over cultural capital, he has never given a sound explanation for this brutal fact (Bourdieu 1996, 270). However, as a matter of social struggles, the relative weight of economic vs. cultural capital is not predefined at a fix rate. This leads to a crucial problem of Bourdieu's concept of capital and the social space: While the labeling of the two axis of the social space (volume of capital and its relative composition) suggest or even require that the two types of economic and of cultural capital are measurable in distinct quantities and can be added up and related to each other, there is no straightforward way how such a conversion rate between economic and cultural capital might be derived (Bourdieu 1984, 125 ff.)

While the empirical strategy of detecting the structure of the social space departs from a relational (correspondence) analysis of cultural practices and tastes, his theoretical explanation runs in the opposite direction, thereby introducing the concept of habitus as a mediator between structure and praxis: In order to explain the structure of the social space, Bourdieu argues that it is basically the concrete capital portfolio, and the individual trajectory of capital endowment and accumulation over time, that shapes the habitus, which then shapes the cultural practices and tastes (Bourdieu 1989). Thus, in his theoretical model, the space of capital is the fundamental and determining structure of social inequality, which basically produces the cultural practices. ${ }^{\text {i }}$

Yet, Bourdieu has never provided an attempt to measure the social space directly as a space of capital. He further never quantified something like the "overall volume of economic and cultural capital" and the "ratio" of the capital composition - and to our knowledge this has also not been attempted by others. Although we do not propose directly to quantifying measures of economic and cultural capital either, we put forward an approach that at least allows deriving social classes based on a direct assessment of various types of economic and cultural capital. 


\section{A direct approach to measuring the Space of Capital}

The theoretical idea behind this direct operationalization of the space of capital is to understand capital portfolios - i.e., the clustering of specific portfolios of various types of economic and cultural capital - as the outcome of class-specific types of investment strategies. Specific capital portfolios are assumed to represent distinct social strategies of investing into social status: strategies to attain, reproduce, and accumulate capital portfolios. While we cannot measure the underlying investment preferences (and the class habitus) directly, we take the actual clustering of capital portfolios as the outcome of successfully realized investment strategies. ${ }^{\text {ii }}$ In this way, we retain and reinterpret the practical and dynamic nature of Bourdieu's notion of capital. Capital portfolios thus serve as proxies for class specific strategies of resource accumulation.

To this end we need to disaggregate capital as far as possible. For instance, economic capital exists in specific forms of labor earnings, home ownership, stocks or business assets, etc. We assume that these various forms of capital involve different strategies and preferences. For example, home ownership, building loans or life insurances are types of economic capital that typically fulfill an insurance function. They might be accompanied by long-term saving strategies, while savings are obtained from labor income. On the contrary, financial assets, real estate or business property involve high risks (chances for profit and risks of losing) and require a stock of wealth that can be invested in the first place. However, it is the specific combination of various types of capital, i.e. the capital portfolio, which indicates a distinct logic of social practices, or a class-specific habitus. For example, academic education can serve different social strategies when combined with different sets of economic capital. Academic titles either serve as a prerequisite or collective legitimization strategy for entering managerial positions, positions that are accompanied with high labor incomes and financial assets that are invested on the stock market. Or, higher education can serve in contrast as an entrance to academic professions that "earn" a high income because they "deserve" it - in other words, as a gratification and acknowledgement of the value of education as such. In that case, higher education is likely combined with high social security, an outright owned bourgeois house and probably some financial assets that are safely invested in long-running funds. If we only consider single measures of income and education, it is often unclear which one serves the other. Combined with other sets of economic and cultural capital, like wealth and high-brow cultural practices, the 
underlying investment strategies become apparent, at least in terms of probabilities. For this very reason, we focus on the portfolio of disaggregated and comprehensive sets of economic and cultural capital. Based on such an account, social classes can be understood more thoroughly as groups which share certain social strategies and capital endowments. This approach comes close to what Savage and colleagues pointed out: Applying capital as an analytical entity to social class analysis enables investigating how inequalities evolve and how classes accumulate and protect their benefits relative to others (Savage et al. 2005: 43).

\section{Data and Methods}

For our analysis we draw on German household panel data which contain rich information on household's socio-economic resources, including different forms of wealth. The German Socioeconomic Panel Study (GSOEP) was initiated in 1984 in West-Germany and expanded to East Germany right after the fall of the wall in 1989 (Wagner et al. 2007). All household members older than 17 years are personally interviewed on a yearly basis. Today, the survey covers more than 30,000 individuals living in over 11,000 households. In the years 2002, 2007 and 2012, a detailed wealth module was implemented, permitting for in-depth analysis of individual (and households') wealth endowments (Frick et al. 2010). The period of investigation covers the years 2002 to 2012 and thus allows us to further analyze class mobility patterns over time.

We restrict our sample to couples and singles aged 25 to 60 , which may or may not have children. We thus focus on prime age adults living in single, couple or nuclear family households, excluding more complex household types that contain more than two adults. The individuals in these excluded households amount to $16,5 \%$ of all adults aged 25-60 in each of the three years. This is done to ease the aggregation of economic and cultural capital at the household level. All information is aggregated on the household level, assuming couples pool and share their respective individual capitals. ${ }^{\text {iii }}$ All sorts of economic capital are adjusted for inflation and household size. Wealth components are divided by two for couple households and incomes are adjusted according to the new OECD equivalence scale. We assume cultural capital to benefit each partner in a couple undividedly, so that the highest value of each cultural capital component is assigned to both partners of a couple. 
We include different sorts of economic as well as cultural capital in our analysis. The model contains five indicators for economic capital:

- $\quad$ net household income $e^{\text {iv }}$

- income from capital

- net value of home ownership

- net value of assets (financial assets, business assets, tangible assets and further real estate $^{\mathrm{v}}$

- market values of building loans and insurances

We add four indicators for cultural capital:

- highest educational level in the household (highest qualification)

- highest human capital in the household (measured via working experience weighted by the level of required qualification $)^{\mathrm{vi}}$

- highest activity level of highbrow cultural practices ${ }^{\mathrm{vii}}$

- highest activity level of popular cultural practices ${ }^{\text {vii }}$

To group households according to their specific capital portfolios, we apply Latent Class Analysis based on the categorical coding of the various types of capital reported above. LCA is probabilistic type of cluster analysis for categorical variables and well-suited for detecting groups with specific configurations or portfolios of capital (Bacher and Vermunt 2010). Methodologically, it builds on the statistical concept of conditional independence, meaning that individuals are clustered in such a way that the correlation of the various variables within each cluster is zero. LCA is foremost an explorative method that requires substantial interpretation of the results to derive the final model. Formally, the best cluster solution is obtained when the information criteria reach the minimum. Nonetheless, it is even more important that the cluster solution is sense making, stable and valid (Bacher/Vermunt 2010: 564). The model fit statistics (see Table A1 in the appendix) reveal the conventional finding of a decreasing log-likelihood, as well as AIC (Akaike information criteria) and BIC (Bayesian information criteria) with the number of classes increasing. However, the ten-class solution is rather unstable and the Loglikelihood thus cannot be replicated. The nine-class model is stable and shows the smallest 
(stable) information criteria. Based on the comparison of model fit statistics and the inspection and interpretation of different numbers of classes we thus opt for a nine-class model.

We pool the data for the three years 2002, 2007 and 2012, assuming that the overall structure of the social space is constant over this period of time. ${ }^{\mathrm{ix}}$ We use cross-sectional weights as delivered with the SOEP (accounting for the oversampling of various groups and the different sampling and attrition probabilities) for reporting the results. The wealth data in the SOEP are checked, edited and multiply imputed for missing values (Frick et al. 2013). We use all five replicates and therefore repeated each step of the analysis five times. All reported results refer to the mean value of results over the five replicates.

\section{Results: The Space of Capital in Germany, 2002-2012}

We start with presenting the nine latent classes obtained from a cross-sectional analysis of the pooled data. While our analysis is based on the above-mentioned set of indicators, we also describe the resulting classes in terms of additional socio-demographic characteristics. In a second step, we make use of the longitudinal nature of the underlying data and assess class mobility over time. A main focus of the analysis lies on the vertical and horizontal structuring of the classes.

\section{The class structure of capital portfolios: Results from a Latent Class Analysis}

The Lower Class ${ }^{\mathbf{x}}$ is about $12 \%$ of our sample. Members of this class have very low incomes and negative assets, home ownership, building loans and insurance or income from capital. Further, they perform lowest on all forms of cultural capital with almost no one reporting a tertiary education and almost $60 \%$ having not more than basic vocational qualification as the highest educational level in the household. Age is above average, and $60 \%$ are not employed. We find a comparably high number of retirees (10\%) and mainly low-skilled manual and low-skilled service workers (26\% and $25 \%)$. 
Table 1: Nine-class solution with selected indicators for economic capital

\begin{tabular}{|c|c|c|c|c|c|c|}
\hline & Size & $\begin{array}{c}\text { Total } \\
\text { Income }\end{array}$ & Total Assets & $\begin{array}{c}\text { Home } \\
\text { Ownership }\end{array}$ & $\begin{array}{c}\text { Build. } \\
\text { Loans \& } \\
\text { Insurances }\end{array}$ & $\begin{array}{c}\text { Income f. } \\
\text { Capital }\end{array}$ \\
\hline Lower Class & $12 \%$ & 6.807 & -2.667 & 3.187 & 604 & 30 \\
\hline $\begin{array}{c}\text { Cultural Lower } \\
\text { Class }\end{array}$ & $6 \%$ & 6.966 & 2.377 & 9.447 & 2.777 & 317 \\
\hline $\begin{array}{c}\text { Lower Middle } \\
\text { Class }\end{array}$ & $18 \%$ & 22.634 & -3.311 & 8.946 & 4.597 & 113 \\
\hline $\begin{array}{c}\text { Cultural Middle } \\
\text { Class }\end{array}$ & $10 \%$ & 31.892 & 3.997 & 13.010 & 6.218 & 188 \\
\hline $\begin{array}{c}\text { Economic Middle } \\
\text { Class }\end{array}$ & $8 \%$ & 24.306 & 12.477 & 36.108 & 16.224 & 550 \\
\hline $\begin{array}{c}\text { Middle Class } \\
\text { Cultural Upper } \\
\text { Middle Class }\end{array}$ & $25 \%$ & 33.041 & 12.554 & 42.041 & 16.496 & 522 \\
\hline $\begin{array}{c}\text { Economic Upper } \\
\text { Middle Class }\end{array}$ & $6 \%$ & 39.624 & 197.608 & 119.973 & 42.031 & 5.945 \\
\hline $\begin{array}{c}\text { Elite } \\
\text { Total }\end{array}$ & $3 \%$ & 83.165 & 355.931 & 139.205 & 51.505 & 12.237 \\
\hline
\end{tabular}

Note: Weighted calculation based on pooled SOEP data, waves 2002, 2007, and 2012. Only household heads and partners aged 25-60 years in nuclear family households. Mean results from five imputed wealth replicates.

The small Cultural Lower Class (6\%) differs from the Lower Class mainly in terms of cultural capital. The economic differences are rather low, as both group show low incomes and almost no wealth. This latent class shows the highest pop cultural practices but also highbrow practices are frequent.

Further, this group is the youngest among our sample, typically lives in single households (58\%), is unmarried (55\%) and half of its members are not working. If working, we find mainly low skilled service occupations (24\%). 
Table 2: Nine-class solution with indicators for cultural capital and age

\begin{tabular}{|c|c|c|c|c|c|c|}
\hline & Size & $\begin{array}{l}\text { Tertiary } \\
\text { Degree }\end{array}$ & $\begin{array}{l}\text { Human } \\
\text { Capital }\end{array}$ & $\begin{array}{l}\text { Highbrow } \\
\text { Cult. } \\
\text { Practices }\end{array}$ & $\begin{array}{c}\text { Popcultural } \\
\text { Practices }\end{array}$ & Age \\
\hline Lower Class & $12 \%$ & $4 \%$ & 1,6 & 1,3 & 1,4 & 43 \\
\hline $\begin{array}{c}\text { Cultural Lower } \\
\text { Class } \\
\end{array}$ & $6 \%$ & $21 \%$ & 1,8 & 2,3 & 2,6 & 38 \\
\hline $\begin{array}{c}\text { Lower Middle } \\
\text { Class }\end{array}$ & $18 \%$ & $5 \%$ & 3,0 & 1,8 & 2,2 & 39 \\
\hline $\begin{array}{l}\text { Cultural Middle } \\
\text { Class }\end{array}$ & $10 \%$ & $91 \%$ & 4,0 & 2,4 & 2,5 & 38 \\
\hline $\begin{array}{c}\text { Economic Middle } \\
\text { Class } \\
\end{array}$ & $8 \%$ & $7 \%$ & 2,7 & 1,2 & 1,2 & 46 \\
\hline Middle Class & $25 \%$ & $8 \%$ & 3,4 & 2,1 & 2,4 & 42 \\
\hline $\begin{array}{l}\text { Cultural Upper } \\
\text { Middle Class }\end{array}$ & $12 \%$ & $87 \%$ & 4,1 & 2,4 & 2,4 & 43 \\
\hline $\begin{array}{l}\text { Economic Upper } \\
\text { Middle Class }\end{array}$ & $6 \%$ & $15 \%$ & 3,1 & 2,1 & 2,2 & 47 \\
\hline Elite & $3 \%$ & $91 \%$ & 4,2 & 2,5 & 2,3 & 46 \\
\hline Total & $100 \%$ & $28 \%$ & 3,1 & 1,9 & 2,2 & 42 \\
\hline
\end{tabular}

Note: Weighted calculation based on pooled SOEP data, waves 2002, 2007, and 2012. Only household heads and partners aged 25-60 years in nuclear family households. Mean results from five imputed wealth replicates.

Above these two lower classes, we find a Lower Middle Class (18\% of the sample). Compared to the Cultural Lower Class this group is characterized by higher average income (although total assets are negative) and a stronger work orientation indicated by higher values for human capital acquired on job, while formal education and cultural practices are lower than in the Cultural Lower Class. A skilled manual worker in fulltime employment is the most common employment type in this latent class. This group is comparably young and mostly married (58\%).

Next, we find three fractions of the middle classes which are characterized by a similar overall level though different composition of capital: The Cultural Middle Class is defined by its broad endowment with cultural capital. This group is highly educated (91\% have tertiary education) and shows a strong human capital alongside with high intensity of cultural practices. Unsurprisingly, we find mainly socio-cultural professionals and semi-professionals (together 30\%) as well as technical experts (19\%) in this latent class. While household's income is well on average, reflecting high returns from cultural capital, all other sorts of economic capital are considerably 
lower than in the other two middle classes. The Cultural Middle Class is one of the classes with very high share of full time work $(71 \%)$.

Compared to the Cultural Middle Class, the Economic Middle Class possesses less cultural capital but we observe a considerable increase in the amount of net worth. Though income from labor is below average, the high overall net worth is mainly due to home ownership and building loans and insurances - thus, it is predominantly wealth that fulfills a security function. Accordingly, we mainly find skilled and low-skilled manual workers of older ages.

The large Middle Class is about $25 \%$ of our sample. Compared to the Economic and the Cultural Middle Class it combines the higher incomes of the Cultural Middle Class with the wealth level of the Economic Middle Class, while the endowment with cultural capital is more in-between. Especially the tertiary degree rate is low while practices are higher than for the Economic Middle Class. This also holds for the mean age which is close to the overall average of our sample. In terms of occupational positions, the Middle Class consists of a broad variety of skilled occupations like routine skilled office workers, skilled manual workers, as well as junior mangers.

Subsequently, we identify two Upper Middle classes, again a more cultural and a more economic fraction:

The Cultural Upper Middle Class (CUMC, 12\%) shows particular high incomes from labor and more than twice as much of financial assets than the Middle Class. However, home ownership is of central importance, as are building loans and insurances. Higher grade manuals and technical experts are found here, together with socio-cultural (semi-)professions. This mid-aged group performs high on all sorts of cultural capital with $87 \%$ having tertiary education.

By contrast, the relatively small Economic Upper Middle Class (EUMC, 6\%) is defined by strong wealth portfolios with much less cultural capital. This group has a diversified wealth portfolio and owns not only profound home ownership, but financial assets as well as building loans and insurances. In fact, this class possesses twice as much financial asset as the Cultural Upper Middle Class. It is the only group (except for the Elite) that owns considerable business assets and real estate. However, income from labor is lower than in the Cultural Upper Middle Class. In terms of occupations, we find mainly the petite bourgeoisie with and without employees as well as managers and even some manual workers (11\%). This group is the oldest group in our 
sample and mainly consists of West Germans. In sum, this class combines the high and diversified economic capital portfolio of the Elite with only average performance on cultural capital which more resembles the Middle Class.

Finally, the Elite is about 6\%. This group performs "best" on all sorts of economic and cultural capital. It shows a highly diversified pool of wealth, including business assets, financial assets, home ownership, further real estate, as well as high incomes. The Elite combines both the high and diversified economic portfolio of the Economic Upper Middle Class with the strong performance on cultural capital of the Cultural Upper Middle Class. Again, this class is almost completely West German. Most adults here are either self-employed, large employers or highergrade managers.

Overall, we find that the nine latent classes are strongly stratified vertically according to the overall volume of capital. In line with Bourdieu's concept of the social space we also find a horizontal differentiation representing the relative composition of cultural and economic capital. Contrary to the absence of any horizontal differentiation in Bourdieu's portrait of the lower classes, we do find a horizontal differentiation between the Lower and the Lower Cultural Class. This is probably due to the increased importance of cultural capital that consequently induced new divisions in the lower classes, e.g. between industrial and service occupations, compared to the 1960s and 1970s (see for example Kriesi 1989; Oesch 2006). This horizontal differentiation in the relative importance of economic versus cultural capital is also strong in the middle and the upper middle classes. From the nine classes, three classes have a predominant cultural profile, found at the lower, the middle and the upper middle level, while two classes have an economic profile, found at the middle and the upper middle level. On the other hand, we do not find a horizontal differentiation at the very top. Rather, the Elite class shows exceptionally high values of both economic and cultural capital. This is somewhat at odds with Bourdieu's understanding that the horizontal differences are strongest at the very top. Of course, this claim probably pertains much more to the symbolic cleavages and struggles between the dominant and the dominated fraction of the dominating classes. This might not be visible based on the more structural indicators of economic and cultural capital that we use. However, in terms of occupational groupings, we also do not find a strong difference between the socio-cultural professions on the one hand and the managers on the other hand. Hence, the interesting question occurs whether the strategies of capital accumulation and investments in the highest layer of the 
social space have changed over the recent decades in such a way that it blurred the traditional cleavages between the "dominated fractions and dominant fractions within the dominant class" (Bourdieu 1984, 470). This might be due to educational expansion and the increased relevance of education and cultural capital for the economic elites, but also due to the economization of cultural capital and socio-cultural occupations, and the increased relevance of wealth for all higher social classes. One possible route to get more insights into the role and stability of the horizontal differentiation is to look at the class mobility over time.

\section{Class Mobility}

Given the longitudinal nature of our data we can assess mobility patterns over time. This is only possible for those who participated in at least two of the three waves of the SOEP in which wealth information was collected. Given that the mobility patterns appear to be similar for the two periods from 2002 to 2007 and from 2007 to 2012, we pooled the data. Table 3 shows the transition matrix (row percentages) between one point in time (2002 or 2007) to five years later (2007 or 2012, respectively).

The cells at the diagonal of the transition table indicate the percentages of individuals from each of the nine classes that remained in the same class five years later. The most stable classes are found at the very bottom of the social space (Lower Class, 74\%) and above the Middle Class. In general, mobility is restricted to neighboring classes along the vertical axis. Yet, we also observe mobility to appear within the horizontal regions of the space of capital. Individuals from the Cultural Lower Class, for instance, are highly mobile and mainly move within the lower part of the distribution, as well as to the Cultural Middle Class. The Cultural Middle Class itself moves primarily into the Cultural Upper Middle Class. But very little mobility appears between the cultural and the economic classes, even within the same vertical layer. For all three classes with a cultural profile, the odds to be mobile into one of the other two cultural classes are far higher than to move into one of the two economic classes, even within the same vertical layer. The same holds, although to a much lesser degree, for the mobility from the two classes with predominantly economic capital. For them, however, we also observe significant downward mobility. Individuals from the Economic Middle Class tend to be mostly mobile into the Middle Class and Lower Middle Class, whereas their richer counterparts, namely individuals from the Economic Upper Middle Class, are predominantly downwardly mobile into the Middle Class. 
Table 3: Mobility across social classes in t (2002 or 2007) and t+5 (2007 or 2012)

\begin{tabular}{|c|c|c|c|c|c|c|c|c|c|c|}
\hline & Lower Class & $\begin{array}{c}\text { Cultural } \\
\text { Lower Class }\end{array}$ & $\begin{array}{c}\text { Lower } \\
\text { Middle Class }\end{array}$ & \begin{tabular}{c|} 
Cultural \\
Middle Class
\end{tabular} & $\begin{array}{l}\text { Economic } \\
\text { Middle Class }\end{array}$ & Middle Class & CUMC & EUMC & Elite & Total \\
\hline Lower Class & 74 & 5 & 12 & 1 & 5 & 3 & 0 & 0 & 0 & 100 \\
\hline $\begin{array}{c}\text { Cultural Lower } \\
\text { Class }\end{array}$ & 13 & 33 & 18 & 19 & 5 & 6 & 5 & 1 & 1 & 100 \\
\hline $\begin{array}{c}\text { Lower Middle } \\
\text { Class }\end{array}$ & 9 & 6 & 51 & 3 & 6 & 23 & 1 & 1 & 0 & 100 \\
\hline $\begin{array}{l}\text { Cultural Middle } \\
\text { Class }\end{array}$ & 2 & 3 & 5 & 49 & 1 & 10 & 29 & 1 & 1 & 100 \\
\hline $\begin{array}{l}\text { Economic } \\
\text { Middle Class }\end{array}$ & 13 & 3 & 21 & 0 & 34 & 22 & 1 & 5 & 0 & 100 \\
\hline Middle Class & 1 & 2 & 13 & 3 & 5 & 65 & 5 & 5 & 0 & 100 \\
\hline $\begin{array}{l}\text { Cultural Upper } \\
\text { Middle Class }\end{array}$ & 0 & 1 & 0 & 10 & 0 & 9 & 69 & 2 & 10 & 100 \\
\hline $\begin{array}{c}\text { Economic Upper } \\
\text { Middle Class } \\
\end{array}$ & 0 & 3 & 6 & 1 & 3 & 21 & 7 & 54 & 5 & 100 \\
\hline Elite & 0 & 0 & 0 & 4 & 1 & 2 & 28 & 6 & 59 & 100 \\
\hline Total & 11 & 5 & 18 & 9 & 7 & 28 & 14 & 6 & 4 & 100 \\
\hline
\end{tabular}

Note: Upstream (row) percentages. Weighted calculation based on pooled SOEP data, waves 2002 to 2007, and 2007 to 2012 . Only household heads and partners aged 25-60 years in nuclear family households. Mean results from five imputed wealth replicates. 
Upward mobility into the Elite is rather limited. Overall, downward mobility rates amount to $34 \%$ and $37 \%$ for the Economic Middle and Economic Upper Middle Classes, respectively. For the corresponding predominantly cultural classes, downward mobility amounts only to $10 \%$ and $20 \%$. This might indicate the stronger risks involved in the strategies of dominantly economic capital accumulation. Accordingly, mobility into the Elite is more likely for members of the Cultural Upper Middle Class as for Economic Upper Middle Class. This emphasizes that a prerequisite for entering elite positions is not only economic capital, but the combination of high economic and high cultural capital.

As expected, we also observe intra-generational mobility to follow a life course pattern. In general, the younger classes of the Cultural Lower Class, Lower Middle Class exert higher mobility rates and most likely still "move" within the social space until members get settled. Additional analyses show that these mobility patterns are similar for men and women ${ }^{\mathrm{xi}}$ and for people with migratory background vs. German natives. Even though the horizontal pattern is similar for different age groups, we observe the youngest group in our sample ( $<35$ years) to be more mobile, whereas the oldest group $(>45)$ is pretty stable and moves exclusively within their respective capital portfolio, if at all.

To sum up, class mobility occurs mainly along the vertical axis but within the distinct horizontal layers of the social space. Cross-profile mobility from e.g. the cultural to the more economic pole is rare to nonexistent. The predominantly cultural classes are particularly unlikely to alter their relative capital composition and are more upwardly mobile than the economic classes and do serve as the main recruiting pool for elite positions.

\section{Conclusions}

The aim of this paper is to construct the "space of capital" based on disaggregated measures of capital portfolios and to analyze the dynamics of class mobility over time. Given the difficulties of extracting single dimensions of economic and cultural capital, we opted for Latent Class Analysis that allows us to directly derive social classes based on the distinct clustering of concrete capital portfolios. When interpreting the nine latent classes, we find clear evidence for the two main axis of the social space, namely the vertical axis of the overall volume of capitals, and the horizontal axis representing the composition of capitals in terms of the relative weight of economic and cultural capital. Further exploration of class mobility reveals the horizontal axis to be stable over time. Most mobility occurs along the vertical axis of the social space, while there is only little horizontal mobility, indicating that individuals rarely change their investment and accumulation strategies. 
Other than expected from Bourdieu's empirical results on the social space of France in 1960s, we did not find the horizontal differentiation to increase with the overall volume of capital. We rather found the horizontal division to be present already in the lower social classes, and we could not detect a horizontal cleavage at the very top. The former finding that a horizontal differentiation is already present at the lower layer of the social space is most likely due to educational expansion and the increased importance of cultural capital for lower social classes due to de-industrialization and new class divisions, e.g. between industrial and service occupations (Hertel 2017; Oesch 2006). The latter finding that the elite class is characterized by both the highest economic and cultural capital is more challenging to understand. On the one hand, the absence of any horizontal division at the top might be due to the low resolution of the cultural capital indicators, which are not capable at grasping major differences and cleavages in cultural practices and symbolic boundaries. For instance, using more detailed information on field of study instead of simply educational levels, or more concrete items on the type of cultural activities and tastes, instead of simply the frequency of highbrow and popular cultural activities (both of which seem to be quite similar) would have allowed to zoom deeper into horizontal divisions of the type of cultural capitals prevalent at the top of the class hierarchy. On the other hand, our findings reveal a particularly strong relevance of cultural capital, even though we only use rather limited indicators of cultural practices. The absence of horizontal differences at the top might, therefore, also reflect important social changes at the top. Cultural capital has gained relevance with the ongoing educational expansion and the rising levels of academic qualifications in top managerial and other elite positions, not the least as a collective legitimation strategy to obtain and defend elite positions (Khan 2011). ${ }^{\text {xii }}$ The empirical findings also suggest that social classes that predominantly invest in economic capital, without parallel strong investments in cultural capital, face greater risks of downward mobility. This is very different from social classes with predominantly cultural capital, which exert higher upward mobility rates, even into the elite class, and are particularly prone to maintain their cultural profile over time (Waitkus and Groh-Samberg forthcoming). At the same time, we clearly find that economic capital is more diversified at higher layers of the social space. In the middle classes, wealth is mostly held in home ownership, building loans and life insurances. Hence, wealth is mostly serving an insurance function in the middle classes, and goes hand in hand with high labor incomes and cultural and human capital investments. More diversified wealth portfolios are a characteristic of those classes focusing primarily on economic capital - with the corresponding risks involved - or the elite. This remains an area of highly interesting research to be done. 


\section{References}

Bacher, Johann, and Jeroen K. Vermunt. 2010. "Analyse latenter Klassen." In Handbuch der sozialwissenschaftlichen Datenanalyse, ed., Christof Wolf and Henning Best, 553-574. Wiesbaden: VS Verlag fur Sozialwissenschaften.

Bennett, Tony, et al. 2009. Culture, Class, Distinction. London, New York: Routledge.

Bourdieu, Pierre. 1984. Distinction. Cambridge: Harvard University Press.

—. 1987. "What Makes a Social Class? On The Theoretical and Practical Existence Of Groups." Berkeley Journal of Sociology 32: 1-17.

—. 1989. "Social Space and Symbolic Power." Sociological Theory 7(1): 14-25.

-. 1996. The state nobility: Elite schools in the field of power. Stanford CA: Stanford University Press.

Coulangeon, Philippe, and Julien Duval (Eds.). 2014. The Routledge Companion to Bourdieu's 'Distinction'. London \& New York: Routledge.

Erikson, Robert, and John H. Goldthorpe. 1992. The Constant Flux. A study of Class Mobility in Industrial Societies. Oxford: Clarendon Press.

Frick, Joachim, et al. 2013. SOEP 2007-Editing und multiple Imputation der Vermögensinformation 2002 und 2007 im SOEP.

Frick, Joachim R, et al. 2010. Editing und multiple Imputation der Vermögensinformation 2002 und 2007 im SOEP. SOEP Survey Papers, 146.

Grabka, Markus M, et al. 2015. "Wealth distribution within couples." Review of Economics of the Household 13(3): 459-486.

Hertel, Florian R. 2017. Social Mobility in the 20th Century. Wiesbaden: VS Verlag für Sozialwissenschaften.

Jenkins, Richard. 1992. Pierre Bourdieu. New York: Routledge.

Khan, Shamus Rahman. 2011. Privilege. The Making of an Adolescent Elite at St. Paul's School. Princeton \& Oxford: Princeton University Press.

Kriesi, Hanspeter. 1989. "New Social Movements and the New Class in the Netherlands." American Journal of Sociology 94(5): 1078-1116.

Lareau, Annette, and Elliot B Weininger. 2003. "Cultural capital in educational research: A critical assessment." Theory and Society 32(5): 567-606.

Le Roux, Brigitte, et al. 2008. "Class and cultural division in the UK." Sociology 42(6): 1049-1071.

Oesch, Daniel. 2006. Redrawing the Class Map. Stratification and Institutions in Britain, Germany, Sweden and Switzerland. New York: Palgrave Macmillan.

Prieur, Annick, and Mike Savage. 2013. "Emerging forms of cultural capital." European Societies 15(2): 246267.

Savage, Mike. 2014. "Piketty's challenge for sociology." The British Journal of Sociology 65(4): 591-606.

-. 2015. "Introduction to elites. From the 'problematic of the proletariat' to a class analysis of 'wealth elites'." The Sociological Review 63(2): 223-239.

Savage, Mike, et al. 2013. "A New Model of Social Class? Findings from the BBC's Great British Class Survey Experiment." Sociology 47(2): 219-250.

Savage, Mike, et al. 2005. "Capital, assets, and resources: some critical issues." The British Journal of Sociology 56(1): 31-47. 
Socio-Economic Panel (SOEP), data for years 1984-2014, version 31, SOEP, 2015, doi:10.5684/soep.v31

Wagner, Gert G, et al. 2007. The German Socio-Economic Panel study (SOEP)-evolution, scope and enhancements. Schmollers Jahrbuch 127(1): 139-169.

Waitkus, Nora, and Olaf Groh-Samberg. forthcoming. "Beyond Meritocracy. Wealth accumulation in German Upper Classes." In New Directions in Elite Studies., ed., Olav Korsnes, Johan Heilbron, Johs. Hjellbrekke, Felix Bühlmann, and Mike Savage, London: Routledge.

Weeden, Kim A., and David B. Grusky. 2005. "The Case for a New Class Map." American Journal of Sociology 111(1): 141-212.

Wright, Erik Olin. 1997. Class Counts: Comparative Studies in Class Analysis. Cambridge: Cambridge University Press.

\section{Appendix}

Table A1: Model Fit Statistics for Nine-class solution

\begin{tabular}{|c|c|c|c|c|c|}
\hline $\begin{array}{c}\text { Number } \\
\text { of classes }\end{array}$ & $\begin{array}{c}\text { Degrees of } \\
\text { Freedom }\end{array}$ & $\begin{array}{c}\text { Log- } \\
\text { likelihood }\end{array}$ & AIC & BIC & $\begin{array}{c}\text { Sample-size } \\
\text { adj. BIC }\end{array}$ \\
\hline 4 & 998962,4 & $-248012,119$ & 496294,237 & 497377,886 & 496948,861 \\
\hline 5 & 998919,8 & $-246548,877$ & 493435,754 & 494792,322 & 494255,246 \\
\hline 6 & 998921,8 & $-245601,587$ & 491609,175 & 493238,662 & 492593,535 \\
\hline 7 & 998907,2 & $-244710,959$ & 489895,918 & 491798,325 & 491045,147 \\
\hline 8 & 998918,2 & $-244029,902$ & 488601,803 & 490777,129 & 489915,9 \\
\hline 10 & 998888,2 & $-243545,078$ & 487700,155 & 490148,4 & 489179,121 \\
\hline 11 & 998829,6 & $-242845,35$ & 486436,701 & 489430,784 & 488245,402 \\
\hline 12 & 998806,8 & $-242607,616$ & 486029,232 & 489296,234 & 488002,802 \\
\hline
\end{tabular}

Source: Unweighted calculation based on pooled SOEP data, waves 2002, 2007, and 2012.

Only household heads and partners aged 25-60 years in nuclear family households. Mean results from five imputed wealth replicates. 
Table A2: Full LCA-Model with Indicators

\begin{tabular}{|c|c|c|c|c|c|c|c|c|c|}
\hline & Lower Class & $\begin{array}{c}\text { Cultural } \\
\text { Lower Class }\end{array}$ & $\begin{array}{l}\text { Lower } \\
\text { Middle }\end{array}$ & $\begin{array}{l}\text { Cultural } \\
\text { Middle }\end{array}$ & $\begin{array}{l}\text { Economic } \\
\text { Middle }\end{array}$ & $\begin{array}{l}\text { Middle } \\
\text { Class }\end{array}$ & $\begin{array}{l}\text { Cultural } \\
\text { Upper }\end{array}$ & $\begin{array}{c}\text { Economic } \\
\text { Upper }\end{array}$ & Elite \\
\hline Size & $9 \%$ & $5 \%$ & $16 \%$ & $10 \%$ & $9 \%$ & $23 \%$ & $15 \%$ & $7 \%$ & $6 \%$ \\
\hline \multicolumn{10}{|l|}{ HOUSEHOLD INCOME* } \\
\hline $\min / 0.6$ & 0,65 & 0,64 & 0,08 & 0,04 & 0,11 & 0,01 & 0,00 & 0,08 & 0,02 \\
\hline $0.6 / 0.8$ & 0,22 & 0,25 & 0,32 & 0,10 & 0,24 & 0,09 & 0,01 & 0,08 & 0,01 \\
\hline $0.8 / 1.5$ & 0,13 & 0,10 & 0,58 & 0,67 & 0,56 & 0,74 & 0,36 & 0,43 & 0,17 \\
\hline $1.5 / 2$ & 0,00 & 0,01 & 0,02 & 0,14 & 0,07 & 0,13 & 0,37 & 0,20 & 0,16 \\
\hline $2 / \max$ & 0,00 & 0,01 & 0,00 & 0,04 & 0,02 & 0,03 & 0,27 & 0,21 & 0,64 \\
\hline \multicolumn{10}{|l|}{ TOTAL ASSETS } \\
\hline $\mathrm{min} /-2.000$ & 0,18 & 0,13 & 0,34 & 0,21 & 0,13 & 0,13 & 0,06 & 0,04 & 0,02 \\
\hline$-2.000 / 2.000$ & 0,79 & 0,65 & 0,55 & 0,36 & 0,40 & 0,25 & 0,09 & 0,01 & 0,01 \\
\hline $2.000 / 50.000$ & 0,03 & 0,21 & 0,10 & 0,40 & 0,41 & 0,58 & 0,65 & 0,26 & 0,15 \\
\hline $50.000 / 200.000$ & 0,00 & 0,01 & 0,01 & 0,03 & 0,05 & 0,04 & 0,19 & 0,45 & 0,45 \\
\hline $200.000 / \max$ & 0,00 & 0,00 & 0,00 & 0,00 & 0,01 & 0,01 & 0,01 & 0,24 & 0,38 \\
\hline \multicolumn{10}{|l|}{ HOME OWNERSHIP } \\
\hline $\min / 0$ & 0,93 & 0,92 & 0,77 & 0,68 & 0,55 & 0,44 & 0,36 & 0,19 & 0,28 \\
\hline $1 / 50.000$ & 0,04 & 0,03 & 0,15 & 0,18 & 0,16 & 0,20 & 0,17 & 0,10 & 0,05 \\
\hline $50.000 / 100.000$ & 0,02 & 0,02 & 0,05 & 0,10 & 0,17 & 0,21 & 0,24 & 0,22 & 0,11 \\
\hline $100.000 / 200.000$ & 0,01 & 0,02 & 0,02 & 0,03 & 0,10 & 0,14 & 0,19 & 0,34 & 0,32 \\
\hline $200.000 / \max$ & 0,00 & 0,01 & 0,00 & 0,01 & 0,02 & 0,02 & 0,03 & 0,16 & 0,25 \\
\hline \multicolumn{10}{|c|}{ BUILDING LOANS \& INSURANCES } \\
\hline $0 / 1$ & 0,84 & 0,57 & 0,26 & 0,21 & 0,24 & 0,08 & 0,07 & 0,10 & 0,09 \\
\hline $1 / 5.000$ & 0,12 & 0,28 & 0,44 & 0,39 & 0,21 & 0,17 & 0,13 & 0,07 & 0,05 \\
\hline $5.000 / 15.000$ & 0,03 & 0,11 & 0,22 & 0,29 & 0,28 & 0,39 & 0,31 & 0,18 & 0,15 \\
\hline $15.000 / 50.000$ & 0,01 & 0,04 & 0,07 & 0,08 & 0,20 & 0,30 & 0,39 & 0,40 & 0,38 \\
\hline $50.000 / \max$ & 0,00 & 0,00 & 0,01 & 0,03 & 0,06 & 0,05 & 0,09 & 0,25 & 0,32 \\
\hline \multicolumn{10}{|l|}{ INCOME FROM CAPITAL } \\
\hline 0 & 0,74 & 0,36 & 0,22 & 0,14 & 0,09 & 0,03 & 0,01 & 0,03 & 0,02 \\
\hline $0.1 / 159$ & 0,21 & 0,41 & 0,66 & 0,58 & 0,44 & 0,39 & 0,18 & 0,05 & 0,02 \\
\hline $150 / 1.500$ & 0,04 & 0,20 & 0,12 & 0,27 & 0,41 & 0,51 & 0,61 & 0,26 & 0,19 \\
\hline $1.500 / \max$ & 0,00 & 0,03 & 0,01 & 0,01 & 0,06 & 0,07 & 0,20 & 0,66 & 0,77 \\
\hline \multicolumn{10}{|l|}{ EDUCATIONAL LEVEL } \\
\hline no formal education & 0,23 & 0,08 & 0,04 & 0,00 & 0,09 & 0,01 & 0,01 & 0,02 & 0,00 \\
\hline basic vocational training & 0,34 & 0,11 & 0,23 & 0,00 & 0,45 & 0,15 & 0,01 & 0,19 & 0,01 \\
\hline intermediate & 0,36 & 0,28 & 0,55 & 0,04 & 0,34 & 0,53 & 0,03 & 0,49 & 0,04 \\
\hline maturity certificate & 0,04 & 0,32 & 0,13 & 0,10 & 0,04 & 0,22 & 0,08 & 0,14 & 0,05 \\
\hline tertiary education & 0,04 & 0,21 & 0,05 & 0,86 & 0,07 & 0,10 & 0,87 & 0,16 & 0,90 \\
\hline \multicolumn{10}{|l|}{ HUMAN CAPITAL } \\
\hline No work, no training & 0,50 & 0,39 & 0,01 & 0,01 & 0,09 & 0,01 & 0,00 & 0,06 & 0,01 \\
\hline irreg. work+basic & 0,27 & 0,33 & 0,10 & 0,01 & 0,19 & 0,02 & 0,00 & 0,03 & 0,01 \\
\hline reg. work+basic/voc. & 0,12 & 0,13 & 0,21 & 0,02 & 0,19 & 0,10 & 0,02 & 0,14 & 0,03 \\
\hline reg. work+voc. or more & 0,11 & 0,12 & 0,68 & 0,24 & 0,50 & 0,82 & 0,12 & 0,75 & 0,05 \\
\hline fullt work+tert. educ. & 0,00 & 0,02 & 0,00 & 0,72 & 0,03 & 0,05 & 0,86 & 0,02 & 0,91 \\
\hline \multicolumn{10}{|c|}{ HIGHBROW CULTURAL PRACTICES } \\
\hline Never & 0,67 & 0,00 & 0,18 & 0,05 & 0,65 & 0,05 & 0,02 & 0,06 & 0,02 \\
\hline Less frequently & 0,20 & 0,25 & 0,36 & 0,13 & 0,23 & 0,29 & 0,15 & 0,25 & 0,13 \\
\hline Every Month & 0,12 & 0,48 & 0,39 & 0,49 & 0,10 & 0,50 & 0,52 & 0,49 & 0,48 \\
\hline Weekly & 0,01 & 0,27 & 0,08 & 0,34 & 0,02 & 0,16 & 0,31 & 0,20 & 0,38 \\
\hline \multicolumn{10}{|c|}{ POPCULTURAL PRACTICES } \\
\hline Never & 0,61 & 0,03 & 0,07 & 0,06 & 0,69 & 0,03 & 0,05 & 0,14 & 0,09 \\
\hline Less frequently & 0,32 & 0,50 & 0,70 & 0,48 & 0,26 & 0,64 & 0,58 & 0,59 & 0,51 \\
\hline Every Month & 0,06 & 0,34 & 0,19 & 0,39 & 0,04 & 0,28 & 0,31 & 0,23 & 0,34 \\
\hline Weekly & 0,01 & 0,13 & 0,03 & 0,07 & 0,01 & 0,05 & 0,05 & 0,04 & 0,06 \\
\hline
\end{tabular}

Source: Unweighted calculation based on pooled SOEP data, waves 2002, 2007, and 2012. Only household heads and partners aged $25-$

60 years in nuclear family households. Mean results from five imputed wealth replicates 
Table A3: Economic Capital across Social Classes (means in $€$ )

\begin{tabular}{|c|c|c|c|c|c|c|c|c|c|}
\hline & $\begin{array}{c}\text { Income } \\
\text { f. Labor }\end{array}$ & $\begin{array}{c}\text { Net } \\
\text { Wealth }\end{array}$ & $\begin{array}{c}\text { Home } \\
\text { Ownership }\end{array}$ & $\begin{array}{c}\text { Building } \\
\text { Loans and }\end{array}$ & $\begin{array}{c}\text { Income } \\
\text { f. Capital }\end{array}$ & $\begin{array}{c}\text { Financial } \\
\text { Assets }\end{array}$ & $\begin{array}{c}\text { Business } \\
\text { Assets }\end{array}$ & $\begin{array}{c}\text { Real } \\
\text { Estate }\end{array}$ & $\begin{array}{c}\text { Overall } \\
\text { Debts }\end{array}$ \\
\hline Lower Class & 6.807 & 1.123 & 3.187 & 604 & 30 & 157 & 50 & 314 & 5.303 \\
\hline $\begin{array}{c}\text { Cultural Lower } \\
\text { Class }\end{array}$ & 6.966 & 14.600 & 9.447 & 2.777 & 317 & 2.948 & 404 & 816 & 5.235 \\
\hline $\begin{array}{c}\text { Lower Middle } \\
\text { Class }\end{array}$ & 22.634 & 10.232 & 8.946 & 4.597 & 113 & 951 & 673 & 101 & 13.316 \\
\hline $\begin{array}{c}\text { Cultural Middle } \\
\text { Class }\end{array}$ & 31.892 & 23.225 & 13.010 & 6.218 & 188 & 4.901 & 2.939 & 851 & 20.227 \\
\hline $\begin{array}{c}\text { Economic } \\
\text { Middle Class }\end{array}$ & 24.306 & 64.808 & 36.108 & 16.224 & 550 & 6.353 & 4.006 & 4.877 & 19.640 \\
\hline $\begin{array}{c}\text { Middle Class } \\
\text { Cultural Upper }\end{array}$ & 33.041 & 71.091 & 42.041 & 16.496 & 522 & 8.192 & 4.665 & 2.713 & 27.136 \\
\hline Middle Class & 52.418 & 108.327 & 53.057 & 22.869 & 1.333 & 19.990 & 5.587 & 9.353 & 39.531 \\
\hline $\begin{array}{c}\text { Economic Upper } \\
\text { Middle Class }\end{array}$ & 39.624 & 359.613 & 119.973 & 42.031 & 5.945 & 40.253 & 71.540 & 91.919 \\
\hline $\begin{array}{c}\text { Elite } \\
\text { Total }\end{array}$ & 83.165 & 546.640 & 139.205 & 51.505 & 12.237 & 110.656 & 120.970 & 134.382 \\
\hline (29.942 & 80.324 & 35.238 & 14.016 & 1.152 & 11.832 & 10.820 & 12.243 & 25.215 \\
\hline
\end{tabular}

Source: Weighted calculation based on pooled SOEP data, waves 2002, 2007, and 2012. Only household heads and partners aged 25-60 years in nuclear family households. Mean results from five imputed wealth replicates.

i We do not engage here with the theoretical controversies over Bourdieu's theory of the habitus, which has been criticized for being too deterministic and static (Jenkins 1992).

ii This strategy ignores the fact that strategies of capital accumulation my simply fail, so that the actual capital composition of a given household may not represent its original strategies. While this is true at the individual level, our analyses operates at the level of social groups, or classes. The likelihood of failures, or of any other type of individual deviations between social strategies and actual outcomes of capital accumulation, is part of the overall probability distribution of class membership.

iii This assumption is certainly a simplification of the inequalities within households, in particular with respect to withincouple wealth inequality - see Grabka et al. (2015).

iv We use household's total net income minus income from asset flows.

$v$ The net value of assets is constructed as follows: net value of further real estate + market value of financial assets + market value of business assets + market values of tangible assets + property debt - other debts.

vi The proxy for human capital is the type of employment $(0=$ not working; $1=$ sporadic employment, $2=$ part-time employment, $3=$ fulltime employment $)$ multiplied by educational level needed for the employment performed $(0=$ no education, $1=$ basic briefing, no education, $2=$ formal instructions or classes, $3=$ vocational training, $4=$ higher vocational training/lower tertiary degree, $5=$ tertiary education). 
vii This proxy for highbrow cultural activities is the mean of (1) attendance of opera, theatre, classical concerts or exhibitions and (2) being culturally active in music, theatre, drawing, photography, or dancing. Both variables are measured on a scale from 1 (never) to 4 (daily). The highest mean is assigned to all household members,

viii The proxy for popular cultural practices is the most frequent attendance of cinema, pop concerts, disco, sport events of a household member from never (1) to daily (4).

ix As a robustness check, we performed the LCA using only one single point of observation (i.e., 2002, 2007 and 2012). The results are pretty robust, with some smaller deviations for the first year of 2002.

$\mathrm{x}$ For a full description of the nine classes see table A2 in the appendix.

xi The main difference between men and women is the increasing stability of the Lower Class when only considering men.

xii The absence of marked differences in the capital portfolios at the top of the German social space might also reflect to some extent peculiarities of the German class system, with its strong civil servants ("Beamtentum") that obtain high wages based on academic qualifications, allowing them constant wealth accumulation over time and - thanks to the strong educational inequalities - across generations. 